\title{
CHARACTERIZING FISH COMMUNITY DIVERSITY ACROSS VIRGINIA LANDSCAPES: PREREQUISITE FOR CONSERVATION
}

\author{
Paul L. Angermeier ${ }^{1}$ And Matthew R. Winston ${ }^{2,3}$ \\ ${ }^{1}$ United States Geological Survey, Virginia Cooperative Fish and Wildlife Research Unit, \\ Department of Fisheries and Wildlife Sciences, Virginia Polytechnic Institute and State University, \\ Blacksburg, Virginia 24061-0321 USA \\ ${ }^{2}$ Department of Fisheries and Wildlife Sciences, Virginia Polytechnic Institute and State University, \\ Blacksburg, Virginia 24061-0321 USA
}

\begin{abstract}
The number of community types occurring within landscapes is an important, but often unprotected, component of biological diversity. Generally applicable protocols for characterizing community diversity need to be developed to facilitate conservation. We used several multivariate techniques to analyze geographic variation in the composition of fish communities in Virginia streams. We examined relationships between community composition and six landscape variables: drainage basin, physiography, stream order, elevation, channel slope, and map coordinates. We compared patterns at two scales (statewide and subdrainage-specific) to assess sensitivity of community classification to spatial scale. We also compared patterns based on characterizing communities by species composition vs. ecological composition. All landscape variables explained significant proportions of the variance in community composition. Statewide, they explained $32 \%$ of the variance in species composition and $48 \%$ of the variance in ecological composition. Typical communities in each drainage or physiography were statistically distinctive. Communities in different combinations of drainage, physiography, and stream size were even more distinctive, but composition was strongly spatially autocorrelated. Ecological similarity and species similarity of community pairs were strongly related, but replacement by ecologically similar species was common among drainage-physiography combinations. Landscape variables explained significant proportions of variance in community composition within selected subdrainages, but proportions were less than at the statewide scale, and the explanatory power of individual variables varied considerably among subdrainages. Community variation within subdrainages appeared to be much more closely related to environmental variation than to replacement among ecologically similar species.

Our results suggest that taxonomic and ecological characterizations of community composition are complementary; both are useful in a conservation context. Landscape features such as drainage, physiography, and water body size generally may provide a basis for assessing aquatic community diversity, especially in regions where the biota is poorly known. Systematic conservation of community types would be a major advance relative to most current conservation programs, which typically focus narrowly on populations of imperiled species. More effective conservation of aquatic biodiversity will require new approaches that recognize the value of both species and assemblages, and that emphasize protection of key landscape-scale processes.
\end{abstract}

Key words: biological conservation; community types; ecological composition; fish communities; geographic correlates; regional diversity; scale effects; species composition.

\section{INTRODUCTION}

The rapid and pervasive human-induced loss of biological diversity (biodiversity) now occurring throughout the world is a serious threat to the quality of life enjoyed by human societies. Biodiversity loss is undesirable on the basis of aesthetic, ecological, economic, and ethical arguments (Ehrlich and Wilson 1991). Conservation of biodiversity challenges ecol-

Manuscript received 24 March 1997; revised 12 February 1998; accepted 4 March 1998; final version received 3 April 1998.

${ }^{3}$ Present address: Missouri Department of Conservation, 1110 South College Drive, Columbia, Missouri 65201 USA. ogists to integrate knowledge across disciplines and spatiotemporal scales and to work in crisis situations (Soule 1985). The most difficult and pressing conservation challenges are related to biodiversity losses over large (e.g., regional) spatial scales. Unfortunately, the small spatial scales, short time frames, and simple assemblages addressed by conventional community ecology provide few principles applicable to large-scale conservation problems (Pimm 1991). Innovative ecological approaches are needed to facilitate effective conservation of the complete spectrum of biodiversity.

The vast majority of conservation efforts focus narrowly on particular species or populations (Noss and Harris 1986, Angermeier and Schlosser 1995). Inade- 
quate conservation of whole communities and ecosystems has allowed dramatic but often unrecognized declines in the diversity of these elements (Williams et al. 1985, Noss et al. 1995, Strittholt and Boerner 1995). Two key advantages of community-level conservation over conservation of individual populations (Angermeier and Schlosser 1995) are that the former is a more cost-effective use of limited resources (Franklin 1993) and that the persistence of populations depends directly on the integrity of the communities in which they are imbedded (Pickett et al. 1992). Indeed, knowledge of community dynamics is critical to understanding longterm, large-scale population dynamics (Pimm 1991). Community-level conservation approaches should complement population-specific programs. A more proactive policy that protected communities before species became endangered would conserve biodiversity more effectively and efficiently (LaRoe 1993, Angermeier and Schlosser 1995, Carroll et al. 1996, Williams and Davis 1996).

Key prerequisites for conserving biodiversity include recognizing how much exists and how much has been lost. For species diversity, conventional taxonomy provides the framework for assessing status and trends. However, a widely accepted taxonomy for communities has not been developed (Orians 1993) despite the perceived need (National Research Council 1993). Classification schemes for terrestrial and wetland communities are more advanced than those for aquatic communities, and usually focus on vegetation (e.g., Scott et al. 1993, The Nature Conservancy 1994, BojorquezTapia et al. 1995). No widely accepted analog for vegetation has been developed to classify aquatic communities, but landscape features such as drainage basin, physiography, and water body size may often be useful (Angermeier and Schlosser 1995). Ecologists can contribute substantially to conservation biology (Doak and Mills 1994) by building models to help answer "How many community types exist?" and "How many have been lost?" Reliable models based on landscape descriptors would be especially valuable in the many regions where biological surveys have not been completed (Kirkpatrick and Brown 1994, Bojorquez-Tapia et al. 1995).

Ideally, a community classification should be based on all co-occurring organisms, but in practice it is likely to be based on taxa that are well known, ecologically important, and valued by society. Recent classifications of aquatic communities for conservation purposes (e.g., Moyle and Ellison 1991, Maxwell et al. 1995, Lammert et al. 1996) indicate that these criteria are best met by fishes. Herein, we focus on geographic distributions of fishes to illustrate patterns of aquatic community diversity.

Fish assemblages can be viewed hierarchically at several spatial scales, and considerable variation in assemblage composition is related to variation in landscape features. Herein, we use "assemblage" to refer generically to any group of populations, and use "community" to refer only to locally interacting populations. Thus, collective populations within a stream reach, within a large watershed, or within an entire continent are assemblages defined at three spatial scales, but only the first assemblage is a community. Zoogeographers often delineate subcontinental regions along the boundaries of major drainage basins with distinctive fish faunas (Moyle and Cech 1988). Landscapes within regions also support distinctive assemblages, which may be distributed according to drainage, physiography, or ecoregion (Hughes et al. 1987, Matthews and Robison 1988, Lyons 1989, Pflieger 1989). Distinct communities within landscapes may occur along gradients of stream size or elevation (Schlosser 1982, Rahel and Hubert 1991, Osborne and Wiley 1992, Lyons 1996), or be associated with particular physicochemical (Taylor et al. 1993) or biotic (Gilliam et al. 1993) features. Variation at each scale contributes to community diversity and is reflected in classifications for conservation purposes (Edwards et al. 1989, Moyle and Ellison 1991, Maxwell et al. 1995, Lammert et al. 1996). Understanding multi-scale phenomena such as diversity requires examination of how patterns change with scale of study (Levin 1992).

Community composition typically is described in terms of the taxa (e.g., species) or ecological attributes (e.g., predators) present. Occurrence of particular taxa may reflect historical processes such as speciation and dispersal or responses to environmental factors such as habitat suitability and biotic interactions. In contrast, the ecological composition of communities more narrowly reflects environmental constraints as illustrated by changes in functional or life history attributes along environmental gradients (Schlosser 1982, Angermeier and Karr 1983, Berkman and Rabeni 1987, Poff and Allan 1995). In a conservation context, both perspectives should be examined. Communities may warrant conservation because of particular component taxa or particular ecological attributes.

Herein, we characterize variation in fish communities across Virginia to seek a framework for assessing and monitoring community diversity. First, we discern distinct community types and identify associations between community variation and landscape features such as drainage basin, physiography, elevation, and stream size. Second, we examine the influence of spatial scale on our ability to detect distinctive communities and their associations with landscape features. Finally, we compare taxonomic and ecological characterizations of fish communities to determine the similarity and utility of classifications generated from the two perspectives. We believe our findings will enhance managers' ability to quantify how much aquatic community diversity occurs in Virginia and to set priorities for its conservation. Further, we expect our approach to be applicable to other regions, including regions where the biota is poorly known. 


\section{Methods}

We analyzed variation among fish communities at two spatial scales, statewide and within selected subdrainages. Each observation was a 1-d sample of a local community. In the terminology of Wiens (1989), our study extent varied (statewide vs. subdrainage) but our study grain (local community) was constant. We included freshwater and diadromous species in our analyses but omitted marine species (following Jenkins and Burkhead 1994). Diadromous fishes migrate between fresh and salt water to spawn.

We separately analyzed two types of data from each sample: a list of native species present and the proportions of those species in each of 47 ecological categories. Proportions were arcsine square-root-transformed prior to analyses. Ecological categories followed Angermeier (1995) and were based on food, habitat, and life history attributes. Each species was assigned to one category for each of 11 ecological variables on the basis of Lee et al. (1980), Jenkins and Burkhead (1994), and personal observation. Communities were characterized by proportions of the species present in each category. Variables and categories are:

Water size-average size of water body inhabited (five categories: small [e.g., creek, pond] to large [e.g., river, lake]).

Number of water sizes-range of water sizes inhabited (three categories).

Trophic level - average trophic level at which adults feed (five categories: algivore, intermediate, invertivore, intermediate, piscivore/parasite).

Number of food types - range of foods eaten (three categories).

Maximum length - greatest recorded total length, in centimeters (five categories: 4-7, 8-15, 16-31, 32-63, $\geq 64)$.

Diadromy-diadromous species are either anadromous (spawn in freshwater) or catadromous (spawn at sea) (two categories: no, yes).

Spawning substrate-substrate in which eggs are laid (five categories: none, pelagic, vegetation, various, mineral).

Water column position-typical distribution of individuals in the water column (two positions: benthic, nonbenthic).

Flow-type of flow required (three categories: lentic, lotic, either).

Age at maturity - typical age at which females first reproduce (ten categories: 0-9 yr).

Nesting behavior - type of nest prepared (four categories: no nest, egg scatterer, cavity/crevice spawner, mound/depression excavator).

\section{Statewide analyses}

Virginia is well suited for our objectives, because it encompasses a wide variety of aquatic habitats which
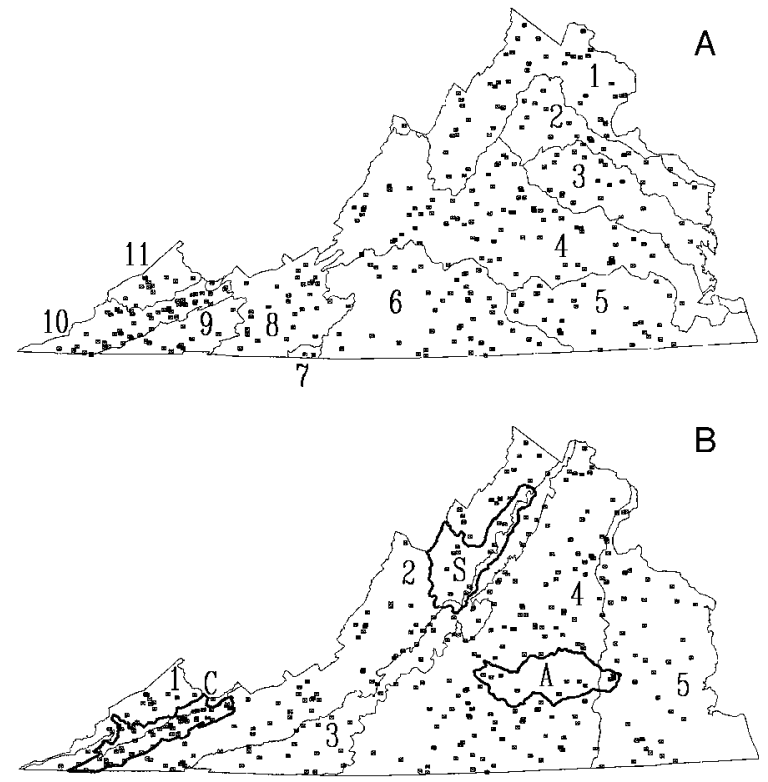

FIG. 1. Maps showing juxtaposition of the 348 sample sites used in statewide analyses with respect to (A) major drainages and (B) physiographies in Virginia. Drainages are numbered as follows: (1) Potomac, (2) Rappahannock, (3) York, (4) James, (5) Chowan, (6) Roanoke, (7) Pee Dee, (8) New, (9) Holston, (10) Clinch-Powell, and (11) Big Sandy. Physiographies are numbered as: (1) Appalachian Plateau, (2) Valley and Ridge, (3) Blue Ridge, (4) Piedmont, and (5) Coastal Plain. The three subdrainages in bold outline $(\mathrm{C}=$ Clinch, $\mathrm{A}=$ Appomattox, and $\mathrm{S}=$ South Fork Shenandoah) were analyzed further.

support a diverse and well known fish fauna (Jenkins and Burkhead 1994). Virginia encompasses portions of 11 major drainages and five physiographic provinces, which are juxtaposed to form $>20$ drainage-physiography combinations (Fig. 1). Over 190 native fish species form a broad array of communities.

Statewide analyses were conducted on 348 fish collections made from 1987 to 1992 under the direction of P. L. Angermeier. A standardized electrofishing protocol was used for each collection; the protocol was designed to capture all fish species present (P. L. Angermeier and R. A. Smogor, unpublished report [1992] to Virginia Department of Game and Inland Fisheries, Richmond, Virginia, USA). Collections represented all major drainages (Fig. 1A), all physiographic provinces (Fig. 1B), and all stream orders greater than third-order within most drainage-physiography combinations. Delineation of drainages and physiographies followed Jenkins and Burkhead (1994). We used several statistical approaches to investigate geographic variation in fish community composition (Table 1).

Variation in community composition.-We examined relationships between community composition and six landscape variables: drainage, physiography, map coordinates, stream order, channel slope, and elevation. Separate analyses were performed for species com- 
TABLE 1. Summary of statistical techniques used to investigate variation in fish community composition across Virginia.

\begin{tabular}{|c|c|c|c|}
\hline Subject & Technique & Purpose & $\begin{array}{l}\text { Presenta- } \\
\quad \text { tion }\end{array}$ \\
\hline \multicolumn{4}{|l|}{ Statewide analyses } \\
\hline Species composition & $\begin{array}{l}\text { Canonical correspondence an- } \\
\text { aylsis (CCA) }\end{array}$ & $\begin{array}{l}\text { To partition community variation into components } \\
\text { associated with six landscape variables: drainage, } \\
\text { physiography, map coordinates, stream order, } \\
\text { channel slope, elevation }\end{array}$ & Table 1 \\
\hline Species composition & $\begin{array}{l}\text { Multi-response permutation } \\
\text { procedures (MRPP) }\end{array}$ & $\begin{array}{l}\text { To test for differences among community types de- } \\
\text { fined by drainage, physiography, and stream order }\end{array}$ & Text \\
\hline Species composition & $\begin{array}{l}\text { Detrended correspondence } \\
\text { analysis (DCA) }\end{array}$ & $\begin{array}{l}\text { To illustrate differences in communities across } \\
\text { drainages, physiographies, and stream orders }\end{array}$ & Fig. 2 \\
\hline Species composition & $\begin{array}{l}\text { Principal coordinates analysis } \\
\text { (PCO) }\end{array}$ & $\begin{array}{l}\text { To illustrate differences among community types } \\
\text { defined by drainage-physiography combinations }\end{array}$ & Fig. 3 \\
\hline Species composition & Kendall's Tau & $\begin{array}{l}\text { To test for spatial autocorrelation in community } \\
\text { composition among drainage-physiography }\end{array}$ & Text \\
\hline $\begin{array}{l}\text { Ecological } \\
\text { composition }\end{array}$ & Redundancy analysis (RDA) & $\begin{array}{l}\text { To partition community variation into components } \\
\text { associated with six landscape variables (same vari- } \\
\text { able as for CCA above) }\end{array}$ & Table 1 \\
\hline $\begin{array}{l}\text { Ecological } \\
\text { composition }\end{array}$ & MRPP & $\begin{array}{l}\text { To test for differences among community types de- } \\
\text { fined by drainage, physiography, and stream order }\end{array}$ & Text \\
\hline $\begin{array}{l}\text { Ecological } \\
\text { composition }\end{array}$ & Correspondence analysis (CA) & $\begin{array}{l}\text { To illustrate differences in communities across } \\
\text { drainages, physiographies, and stream orders }\end{array}$ & Fig. 4 \\
\hline $\begin{array}{l}\text { Ecological } \\
\text { composition }\end{array}$ & $\mathrm{PCO}$ & $\begin{array}{l}\text { To illustrate differences among community types } \\
\text { defined by drainage-physiography combinations }\end{array}$ & Fig. 3 \\
\hline $\begin{array}{l}\text { Ecological } \\
\text { composition }\end{array}$ & Kendall's Tau & $\begin{array}{l}\text { To test for spatial autocorrelation in community } \\
\text { composition among drainage-physiography } \\
\text { combinations }\end{array}$ & Text \\
\hline $\begin{array}{l}\text { Taxonomic and } \\
\text { ecological composi- } \\
\text { tion }\end{array}$ & Pearson's $r$ & $\begin{array}{l}\text { To test the relation between taxonomic and ecological } \\
\text { dissimilarity of all pairs of communities }\end{array}$ & Fig. 5 \\
\hline \multicolumn{4}{|c|}{ Subdrainage-specific analyses } \\
\hline Species composition & $\mathrm{CCA}$ & $\begin{array}{l}\text { To partition community variation into components } \\
\text { associated with five landscape variables: physio- } \\
\text { graphy, map coordinates, stream order, channel } \\
\text { slope, elevation }\end{array}$ & Table 1 \\
\hline Species composition & MRPP & $\begin{array}{l}\text { To test for community differences among watersheds } \\
\text { and among stream orders }\end{array}$ & Text \\
\hline Species composition & DCA & $\begin{array}{l}\text { To illustrate differences in communities across stream } \\
\text { orders }\end{array}$ & Fig. 6 \\
\hline $\begin{array}{l}\text { Ecological } \\
\text { composition }\end{array}$ & RDA & $\begin{array}{l}\text { To partition community variation into components } \\
\text { associated with five landscape variables (same } \\
\text { variables as for CCA above) }\end{array}$ & Table 1 \\
\hline $\begin{array}{l}\text { Ecological } \\
\text { composition }\end{array}$ & MRPP & $\begin{array}{l}\text { To test for community differences among stream } \\
\text { orders }\end{array}$ & Text \\
\hline $\begin{array}{l}\text { Ecological } \\
\text { composition }\end{array}$ & $\mathrm{CA}$ & $\begin{array}{l}\text { To illustrate differences in communities across stream } \\
\text { orders and due to presence/absence of American } \\
\text { eel }\end{array}$ & Fig. 6 \\
\hline $\begin{array}{l}\text { Species and ecologi- } \\
\text { cal composition }\end{array}$ & Pearson's $r$ & $\begin{array}{l}\text { To test the relation between species and ecological } \\
\text { dissimilarity of all pairs of communities }\end{array}$ & Fig. 7 \\
\hline
\end{tabular}

position and ecological composition of communities. We used canonical correspondence analysis (CCA) and redundancy analysis (RDA) via the program CANOCO (ter Braak 1990) to partition community variance into independent components associated with landscape variables. Both CCA and RDA generate ordination axes that are linear combinations of descriptor variables. Thus, the entire multivariate space can be described in terms of the descriptor variables. In our case, RDA assumed a linear relationship and CCA assumed a unimodal relationship between landscape variables and the respective ecological or species turnover (replacement through space). We used CCA for species composition, because considerable species turnover occurs along en- vironmental gradients. We used RDA for ecological composition, because most ecological categories vary in proportion through space but do not replace each other altogether. Preliminary detrended correspondence analyses (DCA), not presented herein, supported our differential treatment of species and ecological composition. Species composition consistently exhibited $>2$ SD of turnover along the first DCA axis; ecological composition consistently exhibited $<2$ SD. ter Braak (1995) recommended 2 SD as the criterion for choosing linear vs. uni-modal ordination models.

We developed spatial models of map coordinates (Borcard et al. 1992, Magnan et al. 1994) and included them in the CCAs and RDAs. Site coordinates (Uni- 
versal Transverse Mercatur; UTM) were normalized using a Box-Cox transformation (Krebs 1989), then centered to zero mean. From the coordinates we calculated the terms for cubic trend surface regressions: $z=x+$ $y+x y+x^{2}+y^{2}+x^{2} y+x y^{2}+x^{3}+y^{3}$, where $x$ and $y$ are UTM coordinates (in meters, increasing from south to north and west to east, respectively). These regression models summarized spatial structure (e.g., linear gradients, patches) among sites. To avoid inflating the explained variance artificially, some terms were eliminated using CANOCO's forward selection procedure. The criterion for term selection was a ratio $>0.10$ of the added variance explained by the term being tested to the variance explained by all terms.

The categorical variables drainage and physiography were coded as dummy variables for CCA and RDA. Stream order (3 to 8$)$, channel slope $(\mathrm{m} / \mathrm{km})$, and elevation $(\mathrm{m})$, taken from 1:24000-scale topographic maps, were normalized using the Box-Cox transformation prior to analysis (Krebs 1989).

We followed Borcard et al. (1992) to partition three components of the variance in community composition: that explained by all landscape variables together; that explained by each variable alone, and that explained by each variable after partitioning out variance also explained by other variables. Each component was compared to zero-effect using a Monte Carlo permutation test on the trace statistic (ter Braak 1990).

Community types. - To examine spatial patterns of variation in community composition, we constructed hypothetical community types from combinations of drainage, physiography, and stream order. We compared communities across 11 drainages, across five physiographies, across two stream sizes (orders 3 to 5 and 6 to 8 ), across 25 drainage-physiography combinations, and across 42 drainage-physiography-streamsize combinations. We judged that comparisons of additional combinations incorporating elevation and channel slope would make the analysis too cumbersome. We chose stream order (over elevation and channel slope) to construct community types, because it was an original criterion for site selection and its range was similar within each drainage and physiography.

We used multi-response permutation procedures (MRPP), a nonparametric discriminant analysis, to test for differences in composition among community types (Biondini et al. 1985, Zimmerman et al. 1985, McCune 1991). Due to the many tests between all possible pairs of community types, we shortened the process by testing only the most similar pairs. First, we calculated the mean Jaccard's similarity (Krebs 1989) between each pair of community types:

$$
\frac{\sum_{i=1}^{N}[a /(a+b+c)]}{N}
$$

where $a=$ the number of species in common between two collections (from different community types), $b=$ the number of species in the first collection not in the second collection, $c=$ the number of species in the second collection not in the first collection, and $N=$ the number of comparisons (all possible pairs of collections between two community types). Pairs of types then were ranked from most to least similar, and MRPP tests were performed on pairs beginning with the most similar and continuing until five consecutive pairs were significantly different $(P<0.05)$. All pairs tested before the five consecutive pairs were considered to be not significantly different. Thus, small differences in composition were less likely to be categorized as significant than if we simply had used $P<0.05$ for each pair tested.

We used DCA, correspondence analysis (CA), and principal coordinates analysis (PCO) to illustrate differences among community types. DCA and CA order assemblages along major gradients of species turnover (ter Braak 1995); PCO provides a plot in which distances between points represent dissimilarities between assemblage types (Pielou 1984). PCO is more appropriate for showing low turnover (as in ecological composition) than high turnover (as in species composition), but we used it for both types of community composition due to lack of a suitable alternative. We drew envelopes around samples of selected community types in DCA and CA plots to illustrate community differences among drainages, among physiographies, and between small and large streams. PCO more clearly illustrated differences among community types defined by combinations of drainage and physiography.

Among drainage-physiography combinations, we tested whether community similarity was related to distance between combinations (i.e., whether composition was spatially autocorrelated). We assigned a distance of 0 if two combinations were adjacent, 1 if they were separated by one combination, 2 if separated by two combinations, and so forth. To control for effects of particular drainages and physiographies, we restricted analyses to distances between physiographies within a drainage and between drainages within a physiography.

Taxonomic vs. ecological dissimilarity.-We investigated the relationship between species dissimilarity and ecological dissimilarity with Jaccard's similarity coefficient (for species composition) and Euclidean distance (for ecological composition). We used 1 Jaccard's to measure species dissimilarity. We computed species and ecological dissimilarity between all possible pairs of the 348 collections, but because the 60378 values were too cumbersome to manipulate, we randomly sampled 500 to plot. We similarly examined the relationship between family composition and ecological composition.

\section{Subdrainage-specific analyses}

We selected three subdrainages for smaller-scale analyses: Clinch, Appomattox, and South Fork Shen- 
andoah. Subdrainages were similar in size, geographically separated, and adequately represented by fish collections. The Clinch is part of the Clinch-Powell drainage and lies within Valley and Ridge and Appalachian Plateau physiographies (Fig. 1B). The mainstem Clinch is sixth-order. The Appomattox is part of the James drainage and lies within Coastal Plain and Piedmont physiographies (Fig. 1B). The South Fork Shenandoah is part of the Potomac drainage and lies within Blue Ridge and Valley and Ridge physiographies (Fig. 1B). Mainstems in the South Fork Shenandoah and Appomattox are seventh-order.

Due to the few PLA collections from these subdrainages, we used a second database of fish community samples collected since 1960 by a variety of investigators (Angermeier and Bailey 1992). This database, which included the PLA collections, provided 290, 96, and 72 collections from the Clinch, Appomattox, and South Fork Shenandoah, respectively. These collections included 85, 61, and 36 species, respectively.

We applied analogs of several statewide analyses to subdrainages (Table 1). We used the same landscape variables to explain variation in community composition and to construct community types. We also compared patterns of variation between species and ecological dissimilarity among subdrainages.

\section{RESUlts}

We present results first for statewide analyses, then for analyses performed in each of the three subdrainages (Table 1). For both scales we analyze spatial variation in species composition and ecological composition and the relation between taxonomic and ecological dissimilarity among community pairs.

\section{Statewide analyses}

Variation in species composition.-All six landscape variables explained significant $(P<0.01)$ proportions of the statewide variance in species composition (CCA results in Table 2). Drainage explained the largest proportion of variance $(21 \%)$ when considered alone, and the largest proportion (9\%) not explained by other variables (Table 2). Physiography and map coordinates also were strong correlates of species composition. Drainage and physiography together explained $27 \%$ of the variance; all variables together explained $32 \%$ of the variance (Table 2).

The DCA plots illustrated striking variation in species composition across Virginia. Given that separation by four DCA units indicates complete species turnover (Gauch 1982), many community pairs were very dissimilar (Fig. 2). Variation in species composition among Coastal Plain communities was underestimated due to omission of marine species, which frequently occurred in freshwater coastal habitats. Although species composition varied continuously across Virginia, several pairs of community types were clearly distinctive (e.g., Chowan vs. New drainages, mountain vs.
Coastal Plain physiographies; Fig. 2). Moreover, all MRPP pairwise comparisons between drainages and between physiographies indicated significant differences $(P<0.001)$ in species composition. The juxtaposition of drainages and physiographies in DCA plots (Fig. 2) reflected geographic distribution (Fig. 1). For example, the New was intermediate between other Mississippi basin drainages and Atlantic slope drainages, and the Piedmont was intermediate between mountain and Coastal Plain physiographies. Stream order was associated with variation in species composition mostly in mountain and Piedmont physiographies (Figs. 2B2C). Overall, small-stream communities differed from large-stream communities $(P<0.001$; MRPP pairwise comparison).

Community types defined by drainage-physiography combinations were more distinctive than types defined by drainage or physiography alone. Only three of 300 (1\%) MRPP pairwise comparisons between such combinations were not significant $(P>0.05$; Fig $3 \mathrm{~A})$. Nonsignificant comparisons occurred between combinations that were adjacent or represented by few collections. A PCO plot of drainage-physiographies (Fig. 3A) showed four main clusters: (1) Mississippi basin combinations (minus the New), (2) Atlantic-mountain combinations (minus the Rappahannock-Blue Ridge, plus the New), (3) Piedmont combinations (minus the York-Piedmont, plus the Rappahannock-Blue Ridge), and (4) Coastal Plain combinations (plus the YorkPiedmont). Additional community types were discernible on the basis of stream size within most combinations (not shown in Fig. 3); only 26 of 903 (3\%) MRPP pairwise comparisons were not significant $(P>$ 0.05). Most nonsignificant comparisons occurred between regions that were adjacent or represented by few collections.

As was the case for communities (Table 2), species composition of drainage-physiography combinations was spatially autocorrelated. Among physiographies within drainages and among drainages within physiographies, mean Jaccard's similarity in species composition varied inversely with distance between combinations (Kendall's Tau $=-0.411[N=20 ; P<0.05]$ and $-0.343[N=56 ; P<0.001]$, respectively).

Variation in ecological composition.-All six landscape variables explained significant $(P<0.01)$ proportions of the statewide variance in ecological composition (RDA results in Table 2). As was the case for species composition, drainage and physiography explained the largest proportions of variance not explained by other variables $(6 \%$ and $3 \%$, respectively; Table 2). These two variables together explained $42 \%$ of the variance. However, when variables were considered individually map coordinates explained the largest proportion $(33 \%)$ of variance, thereby indicating strong spatial autocorrelation in ecological composition.

The CA plots showed considerable variation in eco- 
TABLE 2. Results of canonical correspondence analysis and redundancy analysis showing percentages of variance in community composition (species and ecological) explained by six landscape variables. Results are shown for statewide and three subdrainage-specific analyses.

\begin{tabular}{|c|c|c|c|c|c|c|c|}
\hline & Spatial & Drain & Physiog & Order & Slope & Elev & Total \\
\hline \multicolumn{8}{|l|}{$\begin{array}{l}\text { Statewide } \\
\text { Species }\end{array}$} \\
\hline $\begin{array}{l}\text { Individual } \\
\text { Partial }\end{array}$ & $\begin{array}{r}13.9 \dagger \\
1.9 \dagger\end{array}$ & $\begin{array}{r}21.2 \\
9.3\end{array}$ & $\begin{array}{r}11.6 \\
2.0\end{array}$ & $\begin{array}{l}1.8 \\
0.5\end{array}$ & $\begin{array}{l}3.3 \\
0.6\end{array}$ & $\begin{array}{l}6.7 \\
0.7\end{array}$ & 31.7 \\
\hline \multicolumn{8}{|l|}{ Ecological } \\
\hline $\begin{array}{l}\text { Individual } \\
\text { Partial }\end{array}$ & $\begin{aligned} 33.2 \ddagger \\
1.4 \ddagger\end{aligned}$ & $\begin{array}{r}28.3 \\
6.2\end{array}$ & $\begin{array}{r}28.1 \\
3.1\end{array}$ & $\begin{array}{l}8.8 \\
0.9\end{array}$ & $\begin{array}{r}22.8 \\
1.8\end{array}$ & $\begin{array}{r}30.8 \\
1.0\end{array}$ & 47.6 \\
\hline Statewide (min, max) & & & & $(2,8)$ & $(0,4.39)$ & $(0,765)$ & \\
\hline \multicolumn{8}{|l|}{ Clinch drainage } \\
\hline \multicolumn{8}{|l|}{ Species } \\
\hline $\begin{array}{l}\text { Individual } \\
\text { Partial }\end{array}$ & $\begin{array}{l}8.5 \S \\
4.8 \S\end{array}$ & & $\begin{array}{l}1.4 \\
\mathrm{~ns}\end{array}$ & $\begin{array}{l}6.3 \\
0.8\end{array}$ & $\begin{array}{l}5.5 \\
0.7\end{array}$ & $\begin{array}{l}4.6 \\
0.9\end{array}$ & 14.1 \\
\hline \multicolumn{8}{|l|}{ Ecological } \\
\hline $\begin{array}{l}\text { Individual } \\
\text { Partial }\end{array}$ & $\begin{aligned} 12.3 \| \\
2.5 \|\end{aligned}$ & & $\begin{array}{l}1.9 \\
\mathrm{~ns}\end{array}$ & $\begin{array}{c}14.8 \\
\mathrm{~ns}\end{array}$ & $\begin{array}{r}12.9 \\
1.6\end{array}$ & $\begin{array}{l}9.3 \\
1.2\end{array}$ & 23.5 \\
\hline Clinch (min, $\max )$ & & & & $(2,6)$ & $(0.02,5.47)$ & $(353,841)$ & \\
\hline \multicolumn{7}{|l|}{ Appomattox drainage } & \\
\hline $\begin{array}{l}\text { Individual } \\
\text { Partial }\end{array}$ & $\begin{array}{r}15.6 \mathrm{II} \\
4.8 \mathrm{I}\end{array}$ & & $\begin{array}{c}8.5 \\
\mathrm{~ns}\end{array}$ & $\begin{array}{l}5.3 \\
1.9\end{array}$ & $\begin{array}{c}3.3 \\
\mathrm{~ns}\end{array}$ & $\begin{array}{c}8.0 \\
\text { ns }\end{array}$ & 22.8 \\
\hline \multicolumn{8}{|l|}{ Ecological } \\
\hline $\begin{array}{l}\text { Individual } \\
\text { Partial }\end{array}$ & $\begin{array}{r}15.4 \# \\
3.0 \#\end{array}$ & & $\begin{array}{l}3.0^{*} \\
\mathrm{~ns}\end{array}$ & $\begin{array}{l}\mathrm{ns} \\
\mathrm{ns}\end{array}$ & $\begin{array}{l}4.1^{*} \\
\mathrm{~ns}\end{array}$ & $\begin{array}{r}12.7 \\
\text { ns }\end{array}$ & 20.9 \\
\hline Appomattox (min, max) & & & & $(3,7)$ & $(0,1.29)$ & $(0,199)$ & \\
\hline \multicolumn{8}{|l|}{$\begin{array}{l}\text { South Fork Shenandoah drainage } \\
\text { Species }\end{array}$} \\
\hline $\begin{array}{l}\text { Individual } \\
\text { Partial }\end{array}$ & $\begin{array}{l}19.4 \dagger \dagger \\
7.6^{*}+\dagger\end{array}$ & & $\begin{array}{l}\mathrm{ns} \\
\mathrm{ns}\end{array}$ & $\begin{array}{c}10.7 \\
\mathrm{~ns}\end{array}$ & $\begin{array}{c}8.2 \\
\text { ns }\end{array}$ & $\begin{aligned} & 11.9 \\
& 2.4 *\end{aligned}$ & 25.5 \\
\hline \multicolumn{8}{|l|}{ Ecological } \\
\hline $\begin{array}{l}\text { Individual } \\
\text { Partial }\end{array}$ & $\begin{aligned} 12.5+\ddagger \\
\mathrm{ns}+\end{aligned}$ & & $\begin{array}{l}\mathrm{ns} \\
\mathrm{ns}\end{array}$ & $\begin{array}{c}21.1 \\
\mathrm{~ns}\end{array}$ & $\begin{array}{l}20.8 \\
3.0^{*}\end{array}$ & $\begin{array}{r}26.1 \\
5.2\end{array}$ & 35.1 \\
\hline South Fork Shenandoah (min, $\max )$ & & & & $(3,7)$ & $(0.08,2.78)$ & $(140,743)$ & \\
\hline
\end{tabular}

Note: Geographic variables are: Spatial = spatial model; Drain = drainage; Physiog $=$ physiography; Order $=$ stream order; Slope $=$ channel slope $(\%) ;$ Elev = elevation $(\mathrm{m})$; Individual $=$ variance explained when a variable is the only variable in the model; Partial $=$ variance explained by a variable, but not explained by other variables; Total $=$ variance explained when all variables are in the model. All entries are significantly different from zero effect $(P<0.01)$ except those indicated by asterisks $(* P<0.05)$; "ns" indicates $P>0.05$. Minimum and maximum values taken by Order, Slope, and Elevation are shown in parentheses.

$\dagger z=x+y+x^{2}$

$\ddagger z=x+y+x^{2} y+x^{3}+y^{3}$.

$\S z=x+y+x y+x^{2}+x^{2} y$

$\| z=x+y+x^{2}+x^{2} y$.

II $z=x+x^{2}+x^{3}$.

$\# z=x$.

$\dagger \dagger z=x+x y+x^{2}+y^{2}$.

$\ddagger \ddagger z=x y^{2}$.

logical composition across Virginia. As was the case for species composition (Fig. 2), variation in ecological composition (Fig. 4) was continuous. Some community types were clearly distinctive (e.g., Chowan vs. ClinchPowell drainages; Fig. 4), but overlap among types was more extensive than in plots of species composition. Differences in overlap between Figs. 2 and 4 indicate that many species replacements among communities did not change ecological composition. Nevertheless, all MRPP pairwise comparisons between drainages, be- tween physiographies, and between small- and largestream communities indicated significant differences $(P<0.001)$ in ecological composition.

Community types defined by drainage-physiography combinations were more distinctive than types defined by drainage or physiography alone but not as distinctive as in analyses of species composition (Fig. 3). Many (12\%) MRPP pairwise comparisons of combinations were not significant $(P>0.05$; Fig. 3B). A PCO plot showed one central cluster and two outlying 

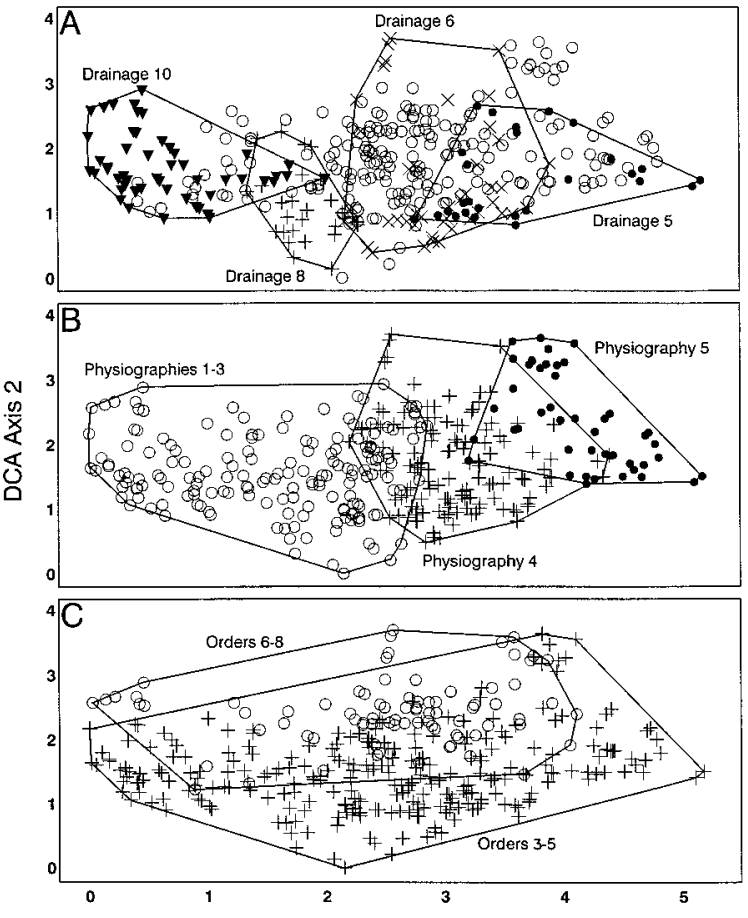

DCA Axis 1

FIG. 2. Ordinations from detrended correspondence analysis (DCA) of the 348 fish collections shown in Fig. 1. Ordinations are based on species composition of each collection. Panels show envelopes circumscribing collections from selected (A) drainages, (B) physiographies, and (C) stream sizes. Drainages and physiographies are numbered as in Fig. 1. For clarity, only drainages 5 (Chowan), 6 (Roanoke), 8 (New), and 10 (Clinch-Powell) are enveloped in panel A. Mountain physiographies (1-3) in panel B and small (3-5) and large (6-8) stream orders in panel $\mathrm{C}$ are also combined for clarity.

clusters. The Holston-Blue Ridge combination was the sole member of one outlying cluster; Coastal Plain combinations formed the other (Fig. 3B). Additional community types were discernible on the basis of stream size within some combinations (not shown in Fig. 3); only $6 \%$ of all MRPP pairwise comparisons were not significant $(P>0.05)$.

As was the case for communities (Table 2), ecological composition of drainage-physiography combinations was spatially autocorrelated. However, autocorrelation was weaker than that observed for species composition. Among physiographies within drainages and among drainages within physiographies, mean dissimilarity in ecological composition (Euclidean distance) was weakly correlated with distance between combinations (Kendall's Tau $=0.324[N=20 ; P=$ $0.081]$ and $0.233[N=56 ; P=0.025]$, respectively).

Taxonomic vs. ecological dissimilarity.-Species dissimilarity was strongly correlated with ecological dissimilarity between communities $(r=0.643 ; N=$ $60378 ; P<0.0001)$. Communities with very similar species composition were necessarily similar ecologi- cally, but communities dissimilar in species composition could be either similar or dissimilar ecologically (Fig. 5A). This pattern reaffirms the notion that ecologically similar species often replace each other among communities. Family dissimilarity was also strongly correlated with ecological dissimilarity ( $r=$ $0.662 ; P<0.0001$ ), but ecological dissimilarity exhibited a similar range of variation for communities with high and low family dissimilarity (Fig. 5B). Communities generally were more similar in family composition than in species composition, but large dissimilarities in family composition were always associated with large dissimilarities in ecological composition.

\section{Subdrainage-specific analyses}

Variation in species composition.-Landscape variables explained significant $(P<0.01)$ proportions of the variance in species composition within subdrainages, but less than in statewide analyses (CCA results in Table 2). Elevation, stream order, and channel slope

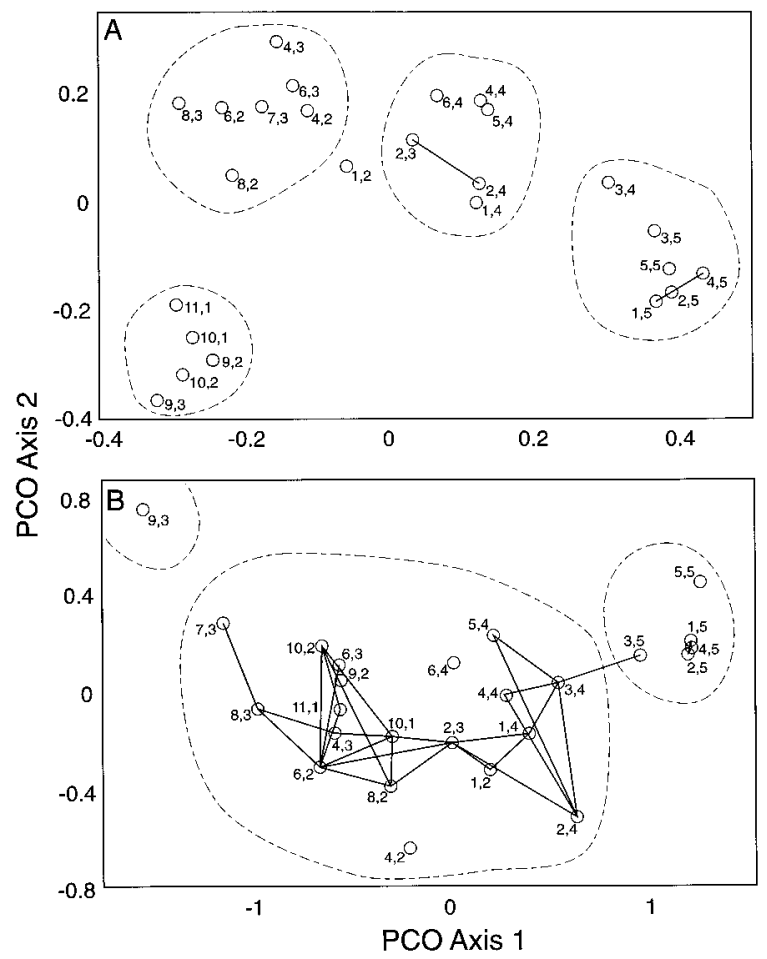

FIG. 3. Ordinations from principal coordinates analysis (PCO) of average similarity in (A) species composition and (B) ecological composition between pairs of hypothetical community types from across Virginia. Community types are defined by combinations of drainage and physiography. Each plotted point represents multiple collections. Distances between points reflect mean Jaccard's similarity of all possible collection pairs from respective community types. The first and second numbers associated with each point refer to the drainages and physiographies, respectively, in Fig. 1. Community types that are not significantly different $(P>0.05$; MRPP pairwise comparisons) are joined with a solid line. Dotted lines circumscribe the clusters of community types described in the text. 

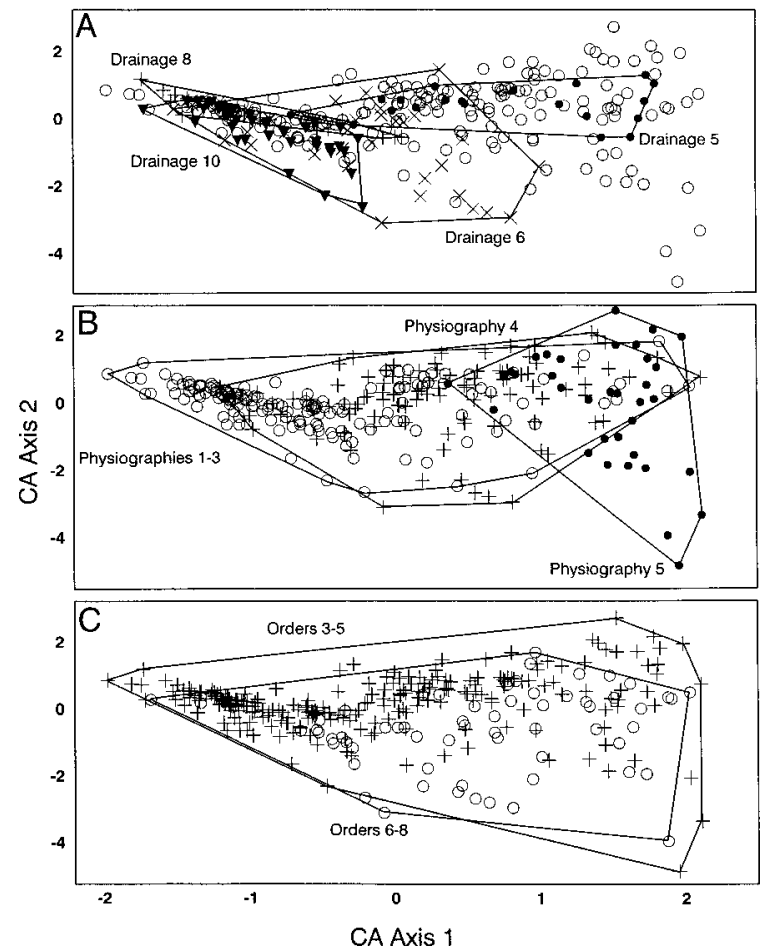

FIG. 4. Ordinations from correspondence analysis (CA) of the 348 fish collections shown in Fig. 1. Ordinations are based on ecological composition of each collection. Format is as in Fig. 2.

individually explained significant proportions of variance in all subdrainages, but none consistently explained a significant proportion not explained by other variables (i.e., intercorrelation was high). The explanatory ability of most variables differed substantially among subdrainages. Unlike the results of statewide analyses, physiography never explained a significant proportion of variance not explained by other variables. Map coordinates consistently explained the greatest proportion of variance in species composition, thereby suggesting that spatial patterns were present but not closely related to the other variables we analyzed.

Similar-sized watersheds within each subdrainage supported distinctive assemblages. We compared species composition of several major watersheds in each subdrainage; all MRPP pairwise comparisons within subdrainages showed significant differences $(P<$ 0.05). For example, Little River and upper Clinch River in the Clinch are confluent, yet mirror shiner (Notropis spectrunculus) and mimic shiner ( $N$. volucellus) were not observed in the 23 collections from Little River, and black sculpin (Cottus baileyi) and Swannanoa darter (Etheostoma swannanoa) were not observed in the 66 collections from upper Clinch River. Similar complementarities in the distribution of species among watersheds were common within all three subdrainages. Although not presented herein, watershed effects were apparent in CCA results for subdrainages just as drain- age effects were apparent in statewide analyses (Table 2 ). For example, when watershed was a variable in a CCA for the Clinch, the proportion of variance in species composition explained increased from 0.14 (Table 2 ) to 0.23 ; watershed explained the greatest proportion (0.09) of variance not explained by other variables. A similar pattern emerged in a RDA of ecological composition; the proportion of variance explained increased from 0.24 (Table 2) to 0.32 .

The DCA plots illustrated considerable variation in species composition within subdrainages. Composition varied continuously, and stream order reflected much of the variation (Fig. 6). Fourteen of the 18 (78\%) MRPP pairwise comparisons between stream orders within subdrainages showed significant differences $(P$ $<0.05)$ in species composition.

Variation in ecological composition.-As was the case for species composition, landscape variables explained significant $(P<0.01)$ proportions of the variance in ecological composition within subdrainages, but less than in statewide analyses (RDA results in Table 2). Map coordinates and elevation individually explained significant proportions of variance in all subdrainages, but neither consistently explained a significant proportion not explained by other variables (Table

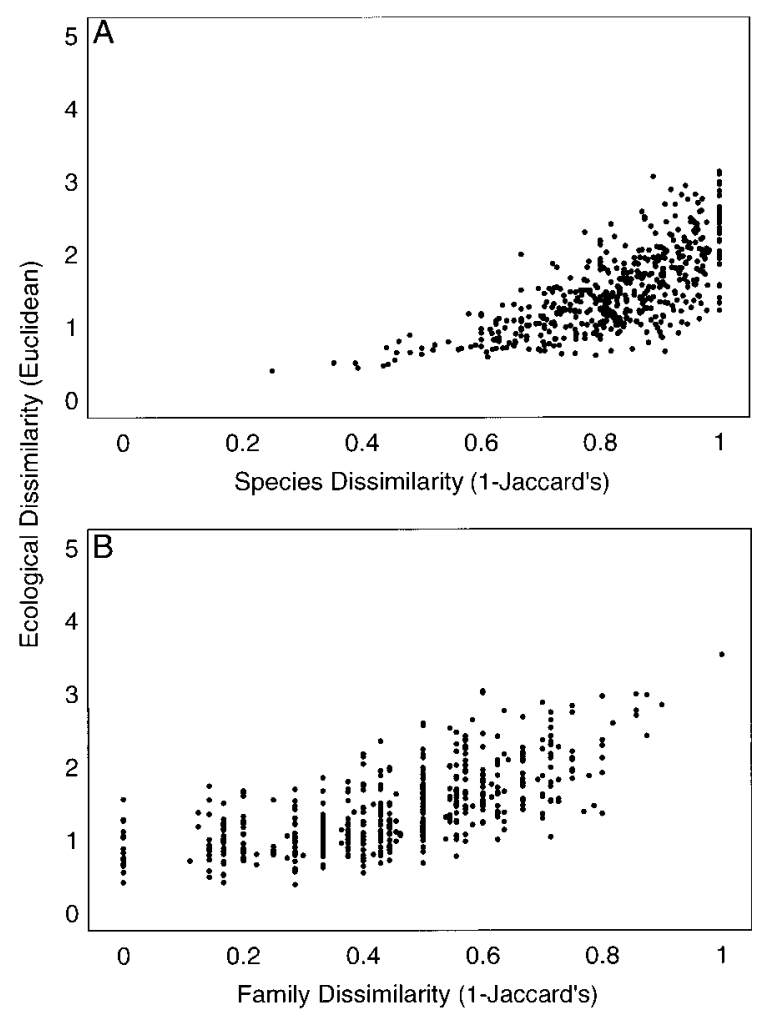

FIG. 5. The relationship between ecological (Euclidean) dissimilarity and taxonomic (1 - Jaccard's) dissimilarity between pairs of 348 fish collections. Taxonomic dissimilarity is shown for the (A) species composition and (B) family composition of each collection. The 500 plotted points in each panel were selected randomly from 60378 possible points. 

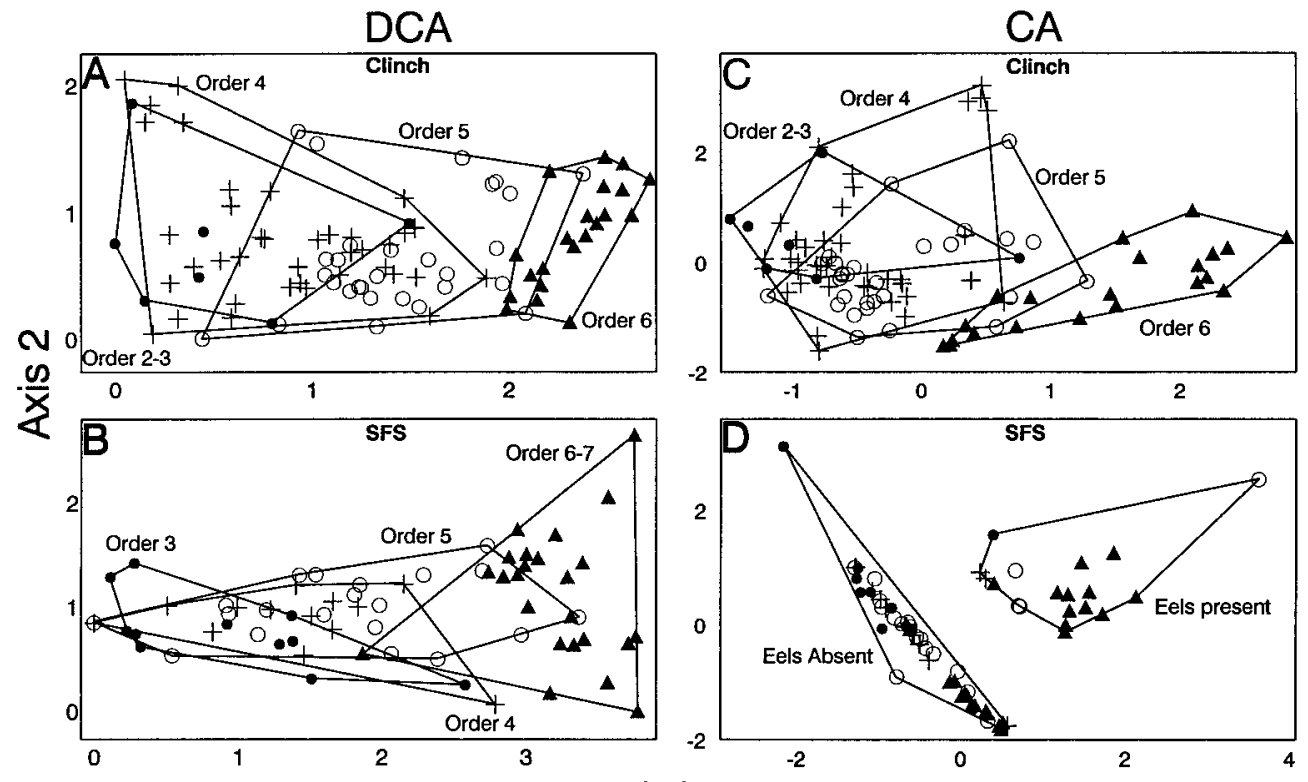

Axis 1

FIG. 6. Fish collection ordinations based on detrended correspondence analysis (DCA) and correspondence analysis (CA). DCA plots reflect species composition of collections; CA plots reflect ecological composition. Ordinations of the Clinch and South Fork Shenandoah (SFS) systems are shown. Four stream sizes are distinguished by different symbols in each plot. Lines circumscribe collections from a given stream size in panels A, B, and C; in panel D lines circumscribe collections in which American eel did and did not occur.

2). Associations between landscape variables and ecological composition were inconsistent among subdrainages. As was the case for species composition, physiography was the weakest correlate of ecological composition within subdrainages. In the Clinch and South Fork Shenandoah, landscape variables explained a greater proportion of the variance in ecological composition than in species composition.

The CA plots illustrated considerable variation in ecological composition within subdrainages. Within the Clinch, composition varied continuously, and stream order reflected much of the variation (Fig. 6C). Five of the six (83\%) MRPP pairwise comparisons between stream orders showed significant differences $(P$ $<0.05)$ in ecological composition. Unlike other ordinations, the CA plots for the Appomattox and South Fork Shenandoah revealed sharp discontinuities in ecological composition (Fig. 6D), which were unrelated to landscape variables. Only five of the $12(42 \%)$ MRPP pairwise comparisons between stream orders showed significant differences $(P<0.05)$ in ecological composition. Rather, the discontinuities largely reflected occurrence of American eel (Anguilla rostrata), the only catadromous species in Virginia and one of the few large piscivores native to these subdrainages. In similar analyses (not presented), with eels omitted from the Appomattox and South Fork Shenandoah data, ecological composition varied continuously, and stream order reflected much of the variation, as was observed for the Clinch (Fig. 6C).

Taxonomic vs. ecological dissimilarity.-Species dissimilarity was strongly correlated $(P<0.0001)$ with ecological dissimilarity between communities within all subdrainages (Fig. 7, $r=0.799$ in the Clinch, 0.779 in the Appomattox, and 0.724 in the South Fork Shenandoah; $N=41905,4560$, and 2485, respectively). As was the case statewide (Fig. 5A), variation in ecological dissimilarity within subdrainages was greater among community pairs with very dissimilar species composition than among community pairs with less dissimilar species composition (Fig. 7). This pattern indicates that ecologically similar species sometimes replace each other among communities. However, the strong correlations between ecological and species dissimilarity within subdrainages indicate that most species turnover is associated with shifts in ecological attributes, which presumably reflect adaptations to environmental conditions.

\section{Discussion}

\section{Geographic variation in fish communities}

The composition of aquatic communities varies considerably across natural landscapes. Conservation of this variation will require ecologists to document general patterns and build working models to explain it. Nonrandom patterns of fish community composition were apparent at each scale we examined, including across drainages statewide, across physiographies within drainages, and across watersheds within subdrainages. Spatial variation in fish communities stems from the interplay between historical barriers to dis- 


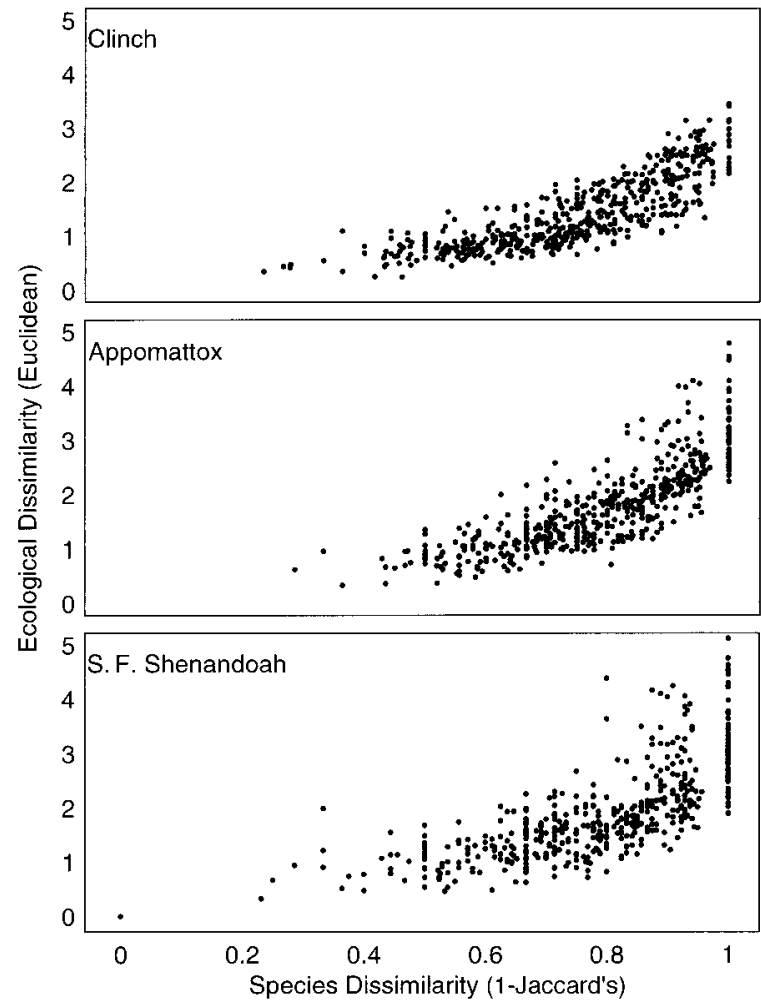

FIG. 7. Relationships between ecological (Euclidean) dissimilarity and species (1 - Jaccard's) dissimilarity between pairs of fish collections within three subdrainages. The 500 plotted points in each panel were selected randomly from all possible points (41905 in the Clinch; 4560 in the Appomattox; 2485 in the South Fork Shenandoah).

persal, which regulate speciation and regional distribution (Hocutt and Wiley 1986, Mayden 1992), and environmental constraints such as flow regime, water chemistry, and predation, which regulate smaller-scale distribution. Much of the variation among Virginia's fish communities can be explained by a few simple landscape descriptors that also explain community variation in other regions. Drainage and physiography often are related to fish community composition in statewide analyses (Hawkes et al. 1986, Hughes et al. 1987, Pflieger 1989), whereas stream size, elevation, and channel slope commonly influence fish communities over smaller spatial scales (Burton and Odum 1945, Schlosser 1982, Rahel and Hubert 1991, Osborne and Wiley 1992, Lyons 1996). These or other landscape descriptors are reasonable components of preliminary models to assess and monitor community diversity.

Our analyses show that most combinations of drainage, physiography, and stream size are distinct in fish community composition. A hierarchical classification framework based solely on these descriptors and elevation (e.g., high- vs. low-elevation streams) yields $\sim 90$ community types for Virginia fresh waters. Analogous frameworks also should be useful in the development of conservation strategies for regions where the biota is poorly known (e.g., Kirkpatrick and Brown 1994, Bojorquez-Tapia et al. 1995). Preliminary estimates of the community diversity in such regions may be derived by merely knowing family composition rather than species composition. Family composition was a stronger correlate of ecological composition of fish communities in Virginia (Fig. 5), a pattern consistent with the notion that most variation in life history traits among current animal species is an artifact of diversification among ancient stocks (Wanntorp et al. 1990, Douglas and Matthews 1992, Owens and Bennett 1995).

No single landscape descriptor is likely to consistently explain variation in community composition across sets of landscapes. A descriptor's explanatory power is probably a function of its range of variation, which typically increases with the area encompassed (Weins 1989), as well as the biota's sensitivity to changes in the descriptor. For example, elevation was a stronger correlate of community composition in montane subdrainages (Clinch, South Fork Shenandoah) than in the Appomattox, which had less topographic relief (Table 1). Strong correlates of community composition in Virginia may be less useful in other regions. In Wisconsin, summer water temperature, largely a function of hydrologic regime, was strongly associated with fish community composition but elevation was not (Lyons 1996). Drainage affiliation, which integrates many influential factors and was a strong correlate of community composition at several scales in Virginia, may be broadly useful in explaining variation among aquatic communities.

Our analytical approach also could be used to monitor temporal changes in geographic patterns of community variation. For example, historical accounts indicate that the distribution and abundance of diadromous fishes has declined dramatically over the past 200 yr (Jenkins and Burkhead 1994). We suspect that ordinations from more natural Virginia landscapes would show more discontinuity between the ecological compositions of Atlantic-slope and inland drainages than shown in Fig. 4A, but less discontinuity within the Appomattox and South Fork Shenandoah (Atlanticslope subdrainages) than shown in Fig. 6D. This sort of re-scaling of patterns of biotic variation commonly occurs in landscapes where humans establish new boundaries, such as barriers to fish movement (Urban et al. 1987).

\section{Characterizing community diversity}

There probably is no best way to characterize community diversity. In a hierarchical framework the number of community types recognized is an increasing function of the number of spatial scales, community attributes, and attribute categories used to build the framework. Ecologists' recognition of differences among communities largely reflects their understanding of community organization. Historical and envi- 
ronmental factors function as a series of "filters" to restrict the number and types of regional species that occur in local communities (Tonn 1990, Poff 1997, Angermeier and Winston 1998). Different combinations of filters produce different community types. The number of community types we recognized (i.e., $\sim 90$ in Virginia) is arbitrary in the sense that a different set of spatial scales, community attributes, and attribute categories could have yielded more or fewer types. For example, if we also had characterized the hydrologic regime of our sites (Poff and Allan 1995), we would have recognized even more community diversity. Alternatively, a clearer understanding of the rules and mechanics of community assembly (Drake 1991) might show that some community types that appear different are merely alternative outcomes or phases of the same organizational process (Bourgeron 1988, Reeves et al. 1995). Protocols for assessing community diversity are poorly developed (Orians 1993, Lapin and Barnes 1995), but we suggest that approaches based on landscape descriptors provide reasonable preliminary estimates for comparing across regions or through time.

Species varied considerably in their influence on apparent community diversity. Species with small distributions and unusual autecologies strongly influenced patterns of variation in species composition and ecological composition, respectively. The catadromous life history of American eel largely controlled patterns of ecological variation within the Appomattox and South Fork Shenandoah. Attributes of most other common species in these subdrainages were relatively similar. The disproportionate influence of American eel on patterns of ecological diversity may seem anomalous or undesirable, but in a conservation context it is instructive. Historically, several diadromous species, including herrings (Alosa), sea basses (Morone), and sturgeons (Acipenser), predominated the structure and function of coastal aquatic systems throughout eastern North America. Communities with viable diadromous populations differed from inland communities in recruitment dynamics, nutrient budgets, and predatorprey interactions. During this century those differences have greatly diminished due to overfishing, dams that prevent access to habitat, and widespread introduction of fishes from other regions (Jenkins and Burkhead 1994). American eel is the most persistent component of a formerly widespread and distinctive community type. The influence of eels on diversity patterns is a relic illustrating recent and largely unrecognized losses of aquatic biodiversity.

Much of the variation in species composition among Virginia fish communities reflected replacement among ecologically similar species. For example, the 42 darter (Percidae) species native to Virginia are very similar with respect to most of our ecological descriptors (see Methods), but only a few typically co-occur in a community. Similarly, four ecologically similar Phenacobius (Cyprinidae) species occur in Virginia, but only two share a major drainage (Jenkins and Burkhead 1994). The correlation between ecological and species dissimilarity was weaker at the statewide scale than within subdrainages (Figs. 5 and 7), thereby indicating that ecological replacement is more common in large regions that encompass landscapes with distinctive phylogenies.

Taxonomic and ecological descriptors provide complementary ways of characterizing fish communities and assessing community diversity. Variation in ecological composition generally reflects variation in environmental constraints, whereas variation in species composition may reflect either environmental variation or phylogenetic history. Variation in species and ecological composition may be confounded if ecologically distinctive species have limited geographic distributions due to dispersal barriers. For example, some communities in the same physiography (similar environmental constraints) but different drainages (different phylogenetic histories) were ecologically dissimilar (Fig. 3B). Species composition is probably more appropriate for assessing community diversity in a conservation context because taxonomic variation more closely reflects genetic variation, an important dimension of biodiversity.

\section{Conserving community diversity}

Designing protocols to assess community diversity is a small but crucial step in developing strategies to conserve aquatic biodiversity. Conservationists must also grapple with the thorny decisions of how much diversity should be conserved, which biotic elements warrant protection, and which management practices will be effective. Thorough treatment of these issues is beyond the scope of this paper, but key points are worth discussing. A classification framework for Virginia based on our analyses of drainage, physiography, stream size, and elevation yields $\sim 90$ types of fish community, virtually all of which are statistically distinctive. Similar numbers of community types have been identified by analogous classifications in Missouri (70 types; Pflieger 1989) and California (150 types; Moyle and Ellison 1991). However, given enough information, we suspect that several hundred community types could be distinguished among the several thousand stream reaches in Virginia. Each type provides its own array of aesthetic, ecological, economic, and ethical value. Although characterizing community diversity is largely a scientific exercise, deciding how much diversity should be conserved is a value-driven societal process. This decision should be informed by careful assessments of historical and current diversity and of the value of that diversity to society.

Our results suggest that priorities for aquatic community conservation could be based on variation in community composition across landscape gradients. Major gradients in Virginia are related to drainage and physiography. Thus, a program to conserve community 
diversity would, at a minimum, need to protect representative communities from each drainage-physiography combination. Representatives along gradients such as stream size, elevation, or hydrologic regime also could be protected to the extent that the citizenry viewed conservation as worthwhile. Implementation of any conservation program focused explicitly on community types would be a significant step forward for aquatic conservation in Virginia and most other regions.

Effective conservation of aquatic biodiversity will require fundamental shifts in the biotic elements and spatial scales to which efforts are applied. The conventional focus on imperiled species or populations leaves most genetic and ecological diversity (following Angermeier and Karr 1994) unprotected, and has not curbed the loss of community diversity (Williams et al. 1985, Noss et al. 1995). Moreover, given the increasing rates of fish species endangerment (Williams et al. 1989, Warren and Burr 1994, Angermeier 1995), the effectiveness of this strategy in conserving populations is questionable. Broader strategies that explicitly protect landscapes and communities, as well as populations, are more likely to be effective (LaRoe 1993, Angermeier and Schlosser 1995, Carroll et al. 1996, Williams and Davis 1996). Communities provide the ecological and evolutionary context for populations; landscapes provide this context for communities. The inherently hierarchical structure of ecosystems dictates that none of these elements can be managed effectively while ignoring the others (Urban et al. 1987, O’Neil et al. 1989).

The conventional practice of establishing a series of isolated reserves is inappropriate to protect aquatic biodiversity. Conservation goals should focus on identifying and protecting key landscape-scale processes such as disturbance and metapopulation dynamics (Reeves et al. 1995, Schlosser and Angermeier 1995), which occur over scales much larger than those typically encompassed by reserves. Human impacts on these processes are the root causes of biodiversity loss (Angermeier and Karr 1994, Folke et al. 1996). Because aquatic ecosystems are inextricably linked to the landscapes they drain, conserving aquatic biodiversity means protecting entire watersheds. Thus, reserves are feasible only for very small aquatic systems (Williams 1991). Innovative, multi-scale approaches that comprise networks of protected areas (including reserves) connected across landscapes and managed as integrated regional components (e.g., Moyle and Yoshiyama 1994, Williams and Davis 1996) are more likely to conserve aquatic biodiversity. These approaches do not require pristine landscapes, but they do require society to recognize that biotas have limited capacities for anthropogenic impacts and to commit to self-imposed limits on the use of global resources. Achieving this commitment is the greatest obstacle to conserving biodiversity.
ACKNOWLEDGMENTS

The Virginia Cooperative Fish and Wildlife Research Unit is jointly sponsored by the U.S. Geological Survey, the Virginia Department of Game and Inland Fisheries, and the Virginia Polytechnic Institute and State University. Field work was supported by grants from Virginia Department of Game and Inland Fisheries. Much of the analyses was supported by a grant from the National Fisheries Research Center-Leetown. We are grateful to R. A. Smogor for assistance with collection and identification of fishes. J. Higgins, J. Lyons, and two anonymous reviewers provided many useful comments on the manuscript.

\section{Literature Cited}

Angermeier, P. L. 1995. Ecological attributes of extinction prone species: loss of freshwater fishes of Virginia. Conservation Biology 9:143-158.

Angermeier, P. L., and A. Bailey. 1992. Use of a geographic information system in the conservation of rivers in Virginia, USA. Pages 151-160 in P. J. Boon, P. Calow, and G. E. Petts, editors. River conservation and management. John Wiley and Sons, New York, New York, USA.

Angermeier, P. L., and J. R. Karr. 1983. Fish communities along environmental gradients in a system of tropical streams. Environmental Biology of Fishes 9:117-135.

Angermeier, P. L., and J. R. Karr. 1994. Biological integrity versus biological diversity as policy directives: protecting biotic resources. BioScience 44:690-697.

Angermeier, P. L., and I. J. Schlosser. 1995. Conserving aquatic biodiversity: beyond species and populations. American Fisheries Society Symposium 17:402-414.

Angermeier, P. L., and M. R. Winston. 1998. Local versus regional influences on local diversity in stream fish communities of Virginia. Ecology 79:911-927.

Berkman, H. E., and C. F. Rabeni. 1987. Effect of siltation on stream fish communities. Environmental Biology of Fishes 18:285-294.

Biondini, M. E., C. D. Bonham, and E. F. Redente. 1985. Secondary successional patterns in a sagebrush (Artemisia tridentata) community as they relate to soil disturbance and soil biological activity. Vegetatio 60:25-36.

Bojorquez-Tapia, L. A., I. Azuara, E. Ezcurra, and O. FloresVillela. 1995. Identifying conservation priorities in Mexico through geographic information systems and modeling. Ecological Applications 5:215-231.

Borcard, D., P. Legendre, and P. Drapeau. 1992. Partialling out the spatial component of ecological variation. Ecology 73: $1045-1055$.

Bourgeron, P. S. 1988. Advantages and limitations of ecological classification for the protection of ecosystems. Conservation Biology 2:218-220.

Burton, G. W., and E. P. Odum. 1945. The distribution of stream fish in the vicinity of Mountain Lake, Virginia. Ecology 26:182-194.

Carroll, R., C. Augspurger, A. Dobson, J. Franklin, G. Orians, W. Reid, R. Tracy, D. Wilcove, and J. Wilson. 1996. Strengthening the use of science in achieving the goals of the Endangered Species Act: an assessment by the Ecological Society of America. Ecological Applications 6:1-11.

Doak, D. F., and L. S. Mills. 1994. A useful role for theory in conservation biology. Ecology 75:615-626.

Douglas, M. E., and W. J. Matthews. 1992. Does morphology predict ecology: hypothesis testing within a freshwater stream fish assemblage. Oikos 65:213-224.

Drake, J. A. 1991. Community-assembly mechanics and the structure of an experimental species ensemble. American Naturalist 137:1-26.

Edwards, R. J., G. Longley, R. Moss, J. Ward, R. Matthews, and B. Stewart. 1989. A classification of Texas aquatic communities with special consideration toward the conservation of endangered and threatened taxa. Texas Journal of Science 41:231-240. 
Ehrlich, P. R., and E. O. Wilson. 1991. Biodiversity studies: science and policy. Science 253:758-762.

Folke, C., C. S. Holling, and C. Perrings. 1996. Biological diversity, ecosystems, and the human scale. Ecological Applications 6:1018-1024.

Franklin, J. F. 1993. Preserving biodiversity: species, ecosystems, or landscapes? Ecological Applications 3:202205.

Gauch, H. G., Jr. 1982. Multivariate analysis in community ecology. Cambridge University Press, New York, New York, USA.

Gilliam, J. F., D. F. Fraser, and M. Alkins-Koo. 1993. Structure of a tropical fish community: a role for biotic interactions. Ecology 74:1856-1870.

Hawkes, C. L., D. L. Miller, and W. G. Layher. 1986. Fish ecoregions of Kansas: stream fish assemblage patterns and associated environmental correlates. Environmental Biology of Fishes 17:267-279.

Hocutt, C. H., and E. O. Wiley, editors. 1986. The zoogeography of North American freshwater fishes. John Wiley and Sons, New York, New York, USA

Hughes, R. M., E. Rexstad, and C. E. Bond. 1987. The relationship of aquatic ecoregions, river basins, and physiographic provinces to the ichthyogeographic regions of Oregon. Copeia 1987:423-432.

Jenkins, R. E., and N. M. Burkhead. 1994. Freshwater fishes of Virginia. American Fisheries Society, Bethesda, Maryland, USA.

Kirkpatrick, J. B., and M. J. Brown. 1994. A comparison of direct and environmental domain approaches to planning reservation of forest higher plant communities and species in Tasmania. Conservation Biology 8:217-224.

Krebs, C. J. 1989. Ecological methodology. Harper and Row, New York, New York, USA.

Lammert, M., J. Higgins, D. Grossman, and M. Bryer. 1996. A classification framework for freshwater communities: Proceedings of The Nature Conservancy's aquatic community classification workshop. The Nature Conservancy, Arlington, Virginia, USA.

Lapin, M., and B. V. Barnes. 1995. Using the landscape ecosystem approach to assess species and ecosystem diversity. Conservation Biology 9:1148-1158.

LaRoe, E. T. 1993. Implementation of an ecosystem approach to endangered species conservation. Endangered Species Update 10(3,4):3-6.

Lee, D. S., C. R. Gilbert, C. H. Hocutt, R. E. Jenkins, D. E McAllister, and J. R. Stauffer, Jr. 1980. Atlas of North American freshwater fishes. North Carolina State Museum of Natural History, Raleigh, North Carolina, USA.

Levin, S. A. 1992. The problem of pattern and scale in ecology. Ecology 73:1943-1967.

Lyons, J. 1989. Correspondence between the distribution of fish assemblages in Wisconsin streams and Omernik's ecoregions. American Midland Naturalist 122:163-182.

Lyons, J. 1996. Patterns in the species composition of fish assemblages among Wisconsin streams. Environmental Biology of Fishes 45:329-346.

Magnan, P., M. A. Rodriguez, P. Legendre, and S. Lacasse. 1994. Dietary variation in a freshwater fish species: relative contribution of biotic interactions, abiotic factors, and spatial structure. Canadian Journal of Fisheries and Aquatic Sciences 51:2856-2865.

Matthews, W. J., and H. W. Robison. 1988. The distribution of the fishes of Arkansas: a multivariate analysis. Copeia 1988:358-374

Maxwell, J. R., C. J. Edwards, M. E. Jensen, S. J. Paustian, H. Parrott, and D. M. Hill. 1995. A hierarchical framework of aquatic ecological units in North America. U.S. Forest Service, General Technical Report NC-176. St. Paul, Minnesota, USA.
Mayden, R. L., editor. 1992. Systematics, historical ecology, and North American freshwater fishes. Stanford University Press, Stanford, California, USA.

McCune, B. 1991. Multivariate analysis on the PC-ORD system. Department of General Science, Oregon State University, Corvallis, Oregon, USA.

Moyle, P. B., and J. J. Cech, Jr. 1988. Fishes: an introduction to ichthyology. Prentice Hall, Englewood Cliffs, New Jersey, USA.

Moyle, P. B., and J. P. Ellison. 1991. A conservation-oriented classification system for the inland waters of California. California Fish and Game 77:161-180.

Moyle, P. B., and R. M. Yoshiyama. 1994. Protection of aquatic biodiversity in California: a five-tiered approach. Fisheries 19(2):6-18.

National Research Council. 1993. A biological survey for the nation. National Academy Press, Washington, D.C., USA.

The Nature Conservancy. 1994. Standardized natural vegetation classification system. NBS/NPS Vegetation mapping program. U.S. Department of Interior National Biological Survey and National Park Service, Washington, D.C., USA.

Noss, R. F., and L. D. Harris. 1986. Nodes, networks, and MUMS: preserving diversity at all scales. Environmental Management 10:299-309.

Noss, R. F., E. T. LaRoe III, and J. M. Scott. 1995. Endangered ecosystems of the United States: a preliminary assessment of loss and degradation. National Biological Service Biological Report 28, Washington, D.C., USA.

O'Neill, R. V., A. R. Johnson, and A. W. King. 1989. A hierarchial framework for the analysis of scale. Landscape Ecology 3:193-205.

Orians, G. H. 1993. Endangered at what level? Ecological Applications 3:206-208.

Osborne, L. L., and M. J. Wiley. 1992. Influence of tributary spatial position on the structure of warm water fish communities. Canadian Journal of Fisheries and Aquatic Sciences 49:671-681.

Owens, I. P. F., and P. M. Bennett. 1995. Ancient ecological diversification explains life-history variation among living birds. Proceedings of the Royal Society of London B 261: 227-232.

Pflieger, W. L. 1989. Aquatic community classification system for Missouri. Aquatic Series No. 19, Missouri Department of Conservation. Jefferson City, Missouri, USA.

Pickett, S. T. A., V. T. Parker, and P. L. Fiedler. 1992. The new paradigm in ecology: implications for conservation biology above the species level. Pages 65-88 in P. L. Fiedler and S. K. Jain, editors. Conservation biology: the theory and practice of nature conservation, preservation, and management. Chapman and Hall, New York, New York, USA.

Pielou, E. C. 1984. The interpretation of ecological data: a primer on classification and ordination. John Wiley and Sons, New York, New York, USA

Pimm, S. L. 1991. The balance of nature? University of Chicago Press, Chicago, Illinois, USA.

Poff, N. L. 1997. Landscape filters and species traits: towards mechanistic understanding and prediction in stream ecology. Journal of the North American Benthological Society 16:391-409.

Poff, N. L., and J. D. Allan. 1995. Functional organization of stream fish assemblages in relation to hydrological variability. Ecology 76:606-627.

Rahel, F. J., and W. A. Hubert. 1991. Fish assemblages and habitat gradients in a Rocky Mountain-Great Plains stream: biotic zonation and additive patterns of community change. Transactions of the American Fisheries Society 120:319332.

Reeves, G. H., L. E. Benda, K. M. Burnett, P. A. Bisson, and 
J. R. Sedell. 1995. A disturbance-based ecosystem approach to maintaining and restoring freshwater habitats of evolutionarily significant units of anadromous salmonids in the Pacific northwest. American Fisheries Society Symposium 17:334-349.

Schlosser, I. J. 1982. Fish community structure and function along two habitat gradients in a headwater stream. Ecological Monographs 52:395-414.

Schlosser, I. J., and P. L. Angermeier. 1995. Spatial variation in demographic processes of lotic fishes: conceptual models, empirical evidence, and implications for conservation. American Fisheries Society Symposium 17:392-401.

Scott, J. M., F. Davis, B. Csuti, R. Noss, B. Butterfield, G. Groves, H. Anderson, S. Caicco, F. D'Erchia, T. C. Ed wards, Jr., J. Ulliman, and R. G. Wright. 1993. Gap analysis: a geographic approach to protection of biological diversity. Wildlife Monograph Number 123, The Wildlife Society, Bethesda, Maryland, USA.

Soule, M. E. 1985. What is conservation biology? BioScience 35:727-734.

Strittholt, J. R., and R. E. J. Boerner. 1995. Applying biodiversity gap analysis in a regional nature reserve design for the Edge of Appalachia, Ohio (U.S.A.). Conservation Biology 9:1492-1505.

Taylor, C. M., M. R. Winston, and W. J. Matthews. 1993. Fish species-environment and abundance relationships in a Great Plains river system. Ecography 16:16-23.

ter Braak, C. J. F. 1990. CANOCO-a FORTRAN program for canonical community ordination by [partial] [detrended] [canonical] correlation analysis, principal components analysis and redundancy analysis (version 3.10). Microcomputer Power, Ithaca, New York, USA.

ter Braak, C. J. F. 1995. Ordination. Pages 91-173 in R. H. G. Jongman, C. J. F. ter Braak, and O. F. R. van Tongeren, editors. Data analysis in community and landscape ecology. Second edition. Cambridge University Press, New York New York, USA.
Tonn, W. M. 1990. Climate change and fish communities: a conceptual framework. Transactions of the American Fisheries Society 119:337-352.

Urban, D. L., R. V. O'Neill, and H. H. Shugart, Jr. 1987. Landscape ecology. BioScience 34:119-127.

Wanntorp, H. E., D. R. Brooks, T. Nilsson, S. Nylin, F. Ronquist, S. C. Stearns, and N. Wedell. 1990. Phylogenetic approaches in ecology. Oikos 57:119-132.

Warren, M. L., Jr., and B. M. Burr. 1994. Status of freshwater fishes of the United States: overview of an imperiled fauna. Fisheries 19(1):6-18.

Wiens, J. A. 1989. Spatial scaling in ecology. Functional Ecology 3:385-397.

Williams, J. E. 1991. Preserves and refuges for native western fishes: history and management. Pages 171-189 in W. L. Minckley and J. E. Deacon, editors. Battle against extinction: native fish management in the American West. University of Arizona Press, Tucson, Arizona, USA.

Williams, J. E., D. B. Bowman, J. E. Brooks, A. A. Echelle, R. J. Edwards, D. A. Hendrickson, and J. J. Landye. 1985. Endangered aquatic ecosystems in North American deserts with a list of vanishing fishes of the region. Journal of the Arizona-Nevada Academy of Science 20:1-62.

Williams, J. E., and G. E. Davis. 1996. Strategies for ecosystem-based conservation of fish communities. Pages 347-358 in R. C. Szaro and D. W. Johnston, editors. Biodiversity in managed landscapes. Oxford University Press, New York, New York, USA.

Williams, J. E., J. E. Johnson, D. A. Hendrickson, S. Contreras-Balderas, J. D. Williams, M. Navarro-Mendoza, D. E. McAllister, and J. E. Deacon. 1989. Fishes of North America endangered, threatened, or of special concern: 1989. Fisheries 14(6):2-20.

Zimmerman, G. M., H. Goetz, and P. W. Mielke, Jr. 1985. Use of an improved statistical method for group comparisons to study effects of prairie fire. Ecology 66:606-611. 